\title{
Cutaneous Adverse Drug Reactions in Hospitalized HIV/AIDS Patients
}

\author{
Yusuf Wibisono, Indropo Agusni, Afif Nurul Hidayati, Rahmadewi, Maylita Sari, \\ Astindari, Septiana, Dwi Murtiastutik \\ Department of Dermatology and Venereology, Faculty of Medicine, Universitas Airlangga/Dr. \\ Soetomo General Academic Hospital, Universitas Airlangga Teaching Hospital, Surabaya, Indonesia
}

\begin{abstract}
Background: Cutaneous adverse drug reaction (CADR) is the most common manifestation of drug hypersensitivity in human immunodeficiency virus (HIV), which presented as maculopapular rash. The incidence of CADR is found to be more common in untreated HIV patients, and the frequency is higher in severe immunodeficiency status. Early diagnosis and appropriate treatment give better outcomes. Purpose: To evaluate the incidence and management of CADR in HIV and acquired immune deficiency syndrome (AIDS) patients. Methods: A retrospective descriptive study of HIV/AIDS patients with CADR who were hospitalized at Intermediate Care and Infectious Disease Centre Dr. Soetomo General Academic Hospital. Result: There were more CADR cases in 2017, accounted 2.35\% of the total Intermediate Care and Infectious Disease Centre RSUD Dr. Soetomo General Academic Teaching Hospital ward patients. There were more male patients (62.5\%), with the most commonly found at the age of $25-44$ years $(64.3 \%)$, and which mostly $(89.3 \%)$ originated from Surabaya. The most common diagnosis was morbiliform eruption (60.7\%), main complaint was red spots all over the body (45\%), all of which are obscure erythematous macules. The most common causes were Duviral + Neviral antiretroviral (46\%) and the most common treatment was dexamethasone injection. Conclusion: The incidence of CADR increased in 2017. The most frequent manifestation was morbilliform eruption due to Duviral+Neviral as the first line ARV treatment. Skin management varies widely in form of topical, oral, and intravenous injection drugs, mostly using steroid class, dexamethasone intravenous injection in particular.
\end{abstract}

Keywords: CADR, HIV, AIDS, antiretroviral, morbiliform eruption, SJS.

Correspondence: Afif Nurul Hidayati, Department of Dermatology and Venereology, Faculty of Medicine, Universitas Airlangga/Dr. Soetomo General Academic Hospital/Universitas Airlangga Teaching Hospital, Surabaya, Indonesia. Email: afif_nurulhidayati@fk.unair.ac.id.

\section{BACKGROUND}

Human Immunodeficiency Virus (HIV) is the cause of acquired immunodeficiency syndrome (AIDS) by weakening the human immune system. ${ }^{1-3}$ Adverse drug reactions (ADR) are a major health problem in outpatient and hospitalized patients. They can be classified as predictable (Type A) and unpredictable reactions (Type B). Type B reactions can be classified as drug intolerance, drug idiosyncrasy, drug allergies, and pseudoallergic reactions. Both types of reactions can be affected by genetic predisposition. Drug included hypersensitivity classification system according to The Gell and Coombs includes Ig-E mediated (Type 1), cytotoxic (Type 2), immune complex (Type 3), and delayed cellular mediated (Type 4). Type 4 hypersensitivity reactions are responsible for delayed cutaneous eruptions such as maculapapular exanthema due to antibiotics and acute generalized exanthematous pustulosis. ${ }^{4}$

HIV patients exhibit complex immunological changes. Multiple drugs that usually prescribed for prevention or treatment of opportunistic infections and antiretroviral therapy (ARV) cause higher risk of drug hypersensitivity reactions in these patients. Cutaneus adverse drug reaction (CADR) is the most common manifestation of drug hypersensitivity in HIV patients which presented as maculopapular rash with or without systemic symptoms and internal organ involvement. The onset is usually delayed and severe cutaneus drug hypersensitivity reactions such as erythema multiforme, Steven Johnson Syndrome (SJS), and Toxic Epidermal Necrolysis (TEN) are more frequent in HIV patients. ${ }^{4}$ The incidence of CADR is more frequent in untreated HIV patients and patients with advanced immunodeficiency status. ${ }^{5}$

To establish the correct diagnosis and treatment of HIV/AIDS patients, early and appropriate treatment provide a better progress or shorter course of disease. Education is also a vital aspect of managing CADR.

\section{METHODS}

A retrospective study of HIV/AIDS patients with CADR, carried out using secondary data from patient medical record who were hospitalized in Intermediate Care and Infectious Disease Centre RSUD Dr. Soetomo General Academic Hospital Surabaya during January $4^{\text {th }} 2016$ to December $30^{\text {th }} 2017$, which were collected from December 2017 until February 2018. 


\section{RESULT}

The total cases of CADR in 2017 was $2.35 \%$ of the total HIV/AIDS patients at the Intermediate Care and Infectious Disease Centre, Dr. Soetomo General Academic Hospital Surabaya. Furthermore, the total cases of CADR from 2016 to 2017 was $1.75 \%$ of the total HIV/AIDS patients at the during the Intermediate Care and Infectious Disease Centre Dr. Soetomo General Academic Hospital. The most infected age group were 25-46 years old (64.3\%) (Figure 1). Mostly were male at $62.5 \%$ and reside in the Surabaya are $(89.3 \%)$. The most common diagnosis was morbilliform drug eruption (60.7\%) and StevenJohnson's Syndrome (SJS) (39.3\%). The most common symptom in morbilliform eruption was rashes all over the body, as observed in 9 patients $(45 \%)$. While in SJS patients, the most common symptoms was rashes all over the body, as observed in 9 patients of morbiliform eruption (45\%) and 7 patients in SJS $(25 \%)$ (Table 1).

Table 1. The symptoms distribution of Cutaneus Adverse Drug Reaction cases complaints in Human Immunodeficiency Virus Infection and Acquired Immune Deficiency Syndrome patients

\begin{tabular}{lll}
\hline Symptoms & Total & (\%) \\
\hline Eruption of morbilliform drugs & & 20 \\
Fever & 4 & 10 \\
Nausea & 2 & 20 \\
Itchy & 4 & 45 \\
Rash on the entire body & 9 & 5 \\
Dry skin & 1 & \\
Steven Johnson Syndrome (SJS) & & 20 \\
Fever & 5 & 12 \\
Itchy & 3 & 28 \\
Rash on the entire body & 7 & 20 \\
Red eye & 5 & 20 \\
Blistered lips & 5 & \\
\hline
\end{tabular}

Duration of symptoms in most patients with morbilliform drug eruption was 1-7 days (58.8\%), 7-14 days $(41.2 \%)$. Duration of symptoms in SJS patients was 1-7 days (100\%). The most common efflorescence in morbilliform drug eruption patients was erythematous macules, morbiliform with indistinct borders $(100 \%)$, while in SJS patients there were erythematous macules with indistinct borders all over the body, the hemorrhagic crust around the mouth, hyperemic conjunctiva and purulent secrets in both eyes were found in 5 patients (33.3\%).

Duviral and nevirapine was the most suspected antiretroviral therapy regimen causing CADR which presented as morbilliform drug eruption in 7 patients $(41.2 \%)$ and as SJS in 6 patients (54.54\%) (Table 2).

Table 2. The distribution of antiretroviral therapy regimen suspected in causing Cutaneus Adverse Drug Reaction in Human Immunodeficiency Virus Infection and Acquired Immune Deficiency Syndrome patients

\begin{tabular}{ccc}
\hline ARV therapy regimen & $\mathrm{n}$ & $(\%)$ \\
\hline Eruption of morbilliform drugs & & \\
Duviral (Zidovudin + Lamivudin) + Nevirapin & 7 & 41.4 \\
Duviral (Zidovudin + Lamivudin) + Efavirenz & 5 & 29.4 \\
Fixed drug combination (Tenovofir + Lamivudin + Efavirenz) & 5 & 29.4 \\
Steven Johnson Syndrome (SJS) & & \\
Duviral (Zidovudin + Lamivudin) + Nevirapin & 6 & 54.5 \\
Tenovofir + Lamivudin + Nevirapin & 5 & 45.5 \\
\hline
\end{tabular}

*ARV $=$ Antiretroviral

The longest duration of ARV therapy in the eruption of morbilliform drugs was duviral + nevirapine for $10-14$ days in 5 patients $(11.8 \%)$, while in SJS was duviral + nevirapine use 10-14 days for 5 patients $(45.45 \%)$ (Table 3$)$. 
Table 3. The distribution of antiretroviral therapy regimen duration to cause Cutaneus Adverse Drug Reaction in Human Immunodeficiency Virus Infection and Acquired Immune Deficiency Syndrome patients

\begin{tabular}{|c|c|c|}
\hline Duration of Use & Total & $(\%)$ \\
\hline \multicolumn{3}{|c|}{ Eruption of morbilliform drugs } \\
\hline \multicolumn{3}{|c|}{ Duviral (Zidovudin + Lamivudin) + Nevirapin } \\
\hline$<10$ days & 2 & 11.7 \\
\hline 10-14 days & 5 & 29.4 \\
\hline$>14-30$ days & - & - \\
\hline 30-90 days & - & - \\
\hline \multicolumn{3}{|c|}{ Duviral (Zidovudin + Lamivudin) + Efavirenz } \\
\hline$<10$ days & 5 & 29.4 \\
\hline \multicolumn{3}{|c|}{ Fixed drug combination (Tenovofir + Lamivudin + Efavirenz) } \\
\hline$<10$ days & 2 & 11.7 \\
\hline 10-14 days & 3 & 17.6 \\
\hline$>14-30$ days & - & - \\
\hline 30-90 days & - & - \\
\hline \multicolumn{3}{|c|}{ Steven Johnson Syndrome (SJS) } \\
\hline \multicolumn{3}{|c|}{ Duviral (Zidovudin + Lamivudin) + Nevirapin } \\
\hline$<10$ days & - & - \\
\hline 10-14 days & 5 & 45.45 \\
\hline$>14-30$ days & 1 & 9.09 \\
\hline 30-90 days & - & - \\
\hline \multicolumn{3}{|c|}{ Tenovofir + Lamivudin + Nevirapin } \\
\hline$<10$ days & 5 & 45.45 \\
\hline
\end{tabular}

The use of drugs other than ARV were cefadroxil patients were unaware of the use of other drugs (26\%). in 2 patients (13\%), paracetamol, pyrimethamine, The diagnosis of SJS was the use of methampirone in clindamycin, anti-tuberculosis drugs, each used by 11 patient $(16 \%)$ and 4 patients (36.4\%) were unknown patient (7\%), cotrimoxazole 3 patients $(20 \%)$ and 4 (Table 4$)$.

Table 4. The Distribution of drug use other than antiretroviral which suspected of causing Cutaneus Adverse Drug Reaction in Human Immunodeficiency Virus Infection and Acquired Immune Deficiency Syndrome patients

\begin{tabular}{llc}
\hline Drugs used & Total & $(\%)$ \\
\hline Morbilliform drug eruption & & 13 \\
Cefadroxil & 2 & 7 \\
Paracetamol & 1 & 7 \\
Clindamicin & 1 & 7 \\
Anti-tuberculosis drugs (OAT) & 1 & 7 \\
Rifampicin & 1 & 7 \\
Pirazinamide & 1 & 7 \\
Isoniazide & 1 & 20 \\
Ethambutol & 3 & 26 \\
Cotrimoxazol & 4 & 16 \\
Unknown & & 16 \\
Steven Johnson Syndrome (SJS) & 1 & 67 \\
Methampyron & 1 & \\
Paracetamol & 4 & \\
Unknown & & \\
\hline
\end{tabular}

*one patient may take more than one drug

The $\mathrm{CD}^{+}$counts distribution were $1-100 \quad 2$ patients $(11.76 \%), 201-349$ cells $/ \mathrm{mm}^{3}$ in 2 patients cell $/ \mathrm{mm}^{3}$ in 5 patients $(29.41 \%), 101-200$ cells $/ \mathrm{mm}^{3}$ in $(11.76 \%)$ and 8 patients $(47.05 \%)$ did not provided 
with $\mathrm{CD}^{+}$counts on patient medical records. Meanwhile, in the diagnosis of Steven Johnson Syndrome, the $\mathrm{CD}^{+}$cound distribution were $1-100$ cell $/ \mathrm{mm}^{3}$ in 3 patients $(27.27 \%), 101-200$ cell $/ \mathrm{mm}^{3}$ in
4 patients $(36.36 \%)$ and 4 patients $(36.36 \%)$ did not provided with $\mathrm{CD} 4^{+}$counts on patient medical records (Figure 1).

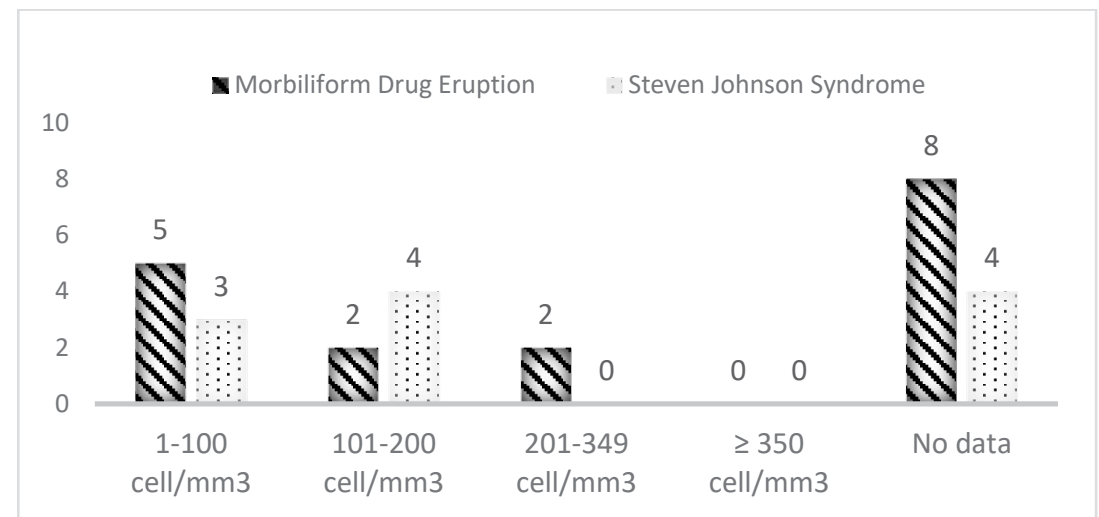

Figure 1. Distribution of $\mathrm{CD}^{+}$counts of Cutaneus Adverse Drug Reaction in Human Immunodeficiency Virus Infection and Acquired Immune Deficiency Syndrome patients

Skin management based on the type of drugs in CADR cases in HIV/AIDS patients in the Intermediate Care and Infectious Disease Centre, Dr. Soetomo General Academic Hospital in 2016-2017 were steroid injection in 16 patients $(29.62 \%)$, oral steroids in 12 patients $(22.22 \%)$, antihistamines in 9 patients $(16.66 \%), \mathrm{NaCl} 0.9 \%$ and salicyl talc in 9 patients $(16.66 \%)$, topical steroids in 5 patients $(9.25 \%)$, and topical antibiotics in 3 patients $(5.55 \%)$ (Figure 2$)$.

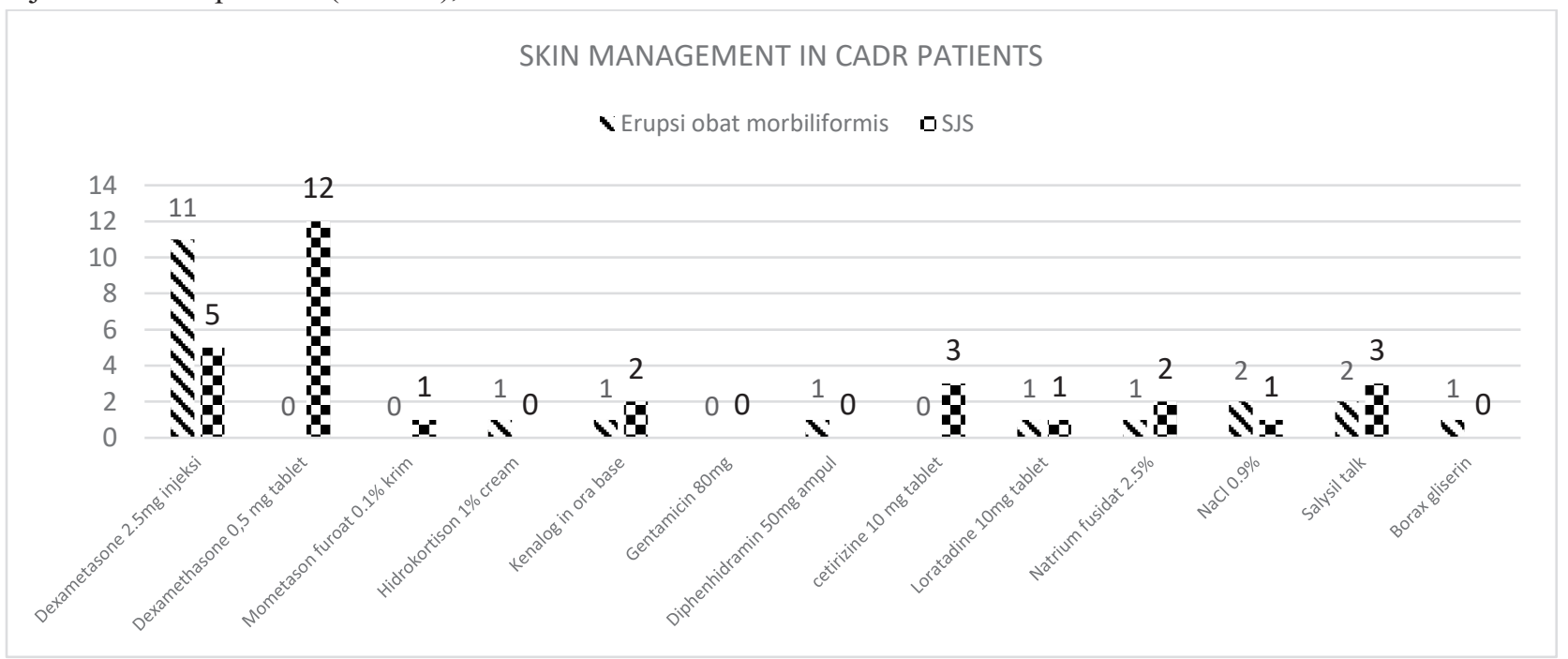

Figure 2. Skin management in Human Immunodeficiency Virus Infection and Acquired Immune Deficiency Syndrome (HIV/AIDS) patients with Cutaneus Adverse Drug Reaction (CADR).

We found that 22 patients $(78.6 \%)$ attended the follow-up visits, 6 patients $(21.4 \%)$ did not attend the follow up visits after the discharge.

\section{DISCUSSION}

There were $28(1.75 \%)$ CADR cases of 1,596 new HIV/AIDS hospitalized patients in Intermediate Care and Infectious Disease Centre, Dr. Soetomo General Academic Hospital in 2016-2017. Furthemore 18 $(64.3 \%)$ of 2018 CADR patients were $25-44$ years of age group, which was likely due to the reproductive stage of age group. This was consistent with the Nigerian study by Agu and Oparah, and they reported $72.2 \%$ of total patients were under 44 years old $19.6 \%$ of them were above 44 years old. ${ }^{6}$ Instead the studies by Eluwa et. al, found that age has no relation with the incidence of CADR. ${ }^{7}$

CADR was reported more in males $(62.5 \%)$ rather than females $(37.5 \%)$. This was in line with research by Srikanth in 2012 and Kumar in 2010 in India. They reported that more CADR patients were males. ${ }^{8}$ Yet several studies in Nigeria reported there was no 
correlation between the incidence of ADR with gender. ${ }^{9-10}$ The correlation between sex and ADR was not fully understood. However, body weight, body mass index, hormonal differences, body fat distribution and genom indifferences have roles in drug metabolism. ${ }^{11}$

Out of the 28 patients with CADR, 25 patients $(89.3 \%)$ live in Surabaya and only 3 patients live outside the area. This was likely because patients seek treatment in the nearest hospital and considering that Dr. Soetomo General Academic Hospital is a referral hospital in Surabaya. Furthermore, patients who lives outside of Surabaya might prefer the nearest health facilities to their residence.

The distribution of CADR cases includes morbilliform drug eruption (60.7\%) and Steven Johnson syndrome (SJS) (39.3\%). Studies have reported that the morbilliform rash is the highest manifestation in the CADR spectrum. Research on the Military Medical Consortium for the Advancement of Retroviral Research followed by 974 HIV patients reported that $95 \%$ of the CADR cases were presented as morbilliform rash. ${ }^{12-13}$ Morbilliform rash are also the most common reaction occurring after ARV therapy. ${ }^{13}$ Morbilliform drug eruption presented as the most common CADR found in HIV/AIDS patients due to nevirapine. In $15-32 \%$ reaction presented as morbiliform rash and can occur within 6 weeks following the initial therapy.

Redness on the entire body was the most common symptoms in $45 \%$ of cases of the morbilliform eruption and and $28 \%$ cases in SJS. The most common clinical findings of morbilliform eruption is erythematous macules with indistinct borders all over the body, as reported in 17 patients $(100 \%)$. In SJS there were erythematous macules with indistinct borders all over the body, the hemorrhagic crust around the mouth, hyperemic conjunctiva and purulent secrets in both eyes as observed in 5 patients $(33.3 \%){ }^{12,14}$

The most suspected antiretroviral regimen drug causing CADR was duviral + nevirapine in 7 patients $(41.2 \%)$ with CADR in the form of SJS was duviral + neviral in 6 patients $(54.54 \%)$. This is in accordance with a study by Pawar et al. in 2015, stated that nevirapine was suspected drug in 39 cases of morbilliform drug eruption and 4 cases of SJS. ${ }^{13}$ In 2011, Sharma reported that maculopapular rash were the most frequent adverse effects of nevirapine, more specifically 13 cases of morbilliform drug eruption and 3 SJS cases. ${ }^{15}$ In this study nevirapine was suspected to cause erythroderma. This was in line with research held by Rooks, which stated that nevirapine drugs could cause erythroderma. ${ }^{1}$ Nevirapine is also one of the easy-to-obtain, effective and inexpensive, thus becoming first-line ARV drugs for HIV/AIDS treatment. ${ }^{2,15}$ In addition, evidence suggests that a strong genetic predisposition to cutaneous reactions with nevirapine and certain Human Leukocyte Antigen (HLA) genotypes that are closely related to CADR events. The formation of electrophilic quinoids during nevirapine metabolism and its covalent reaction with bionucleophyll may also be a mechanism underlying the possibility of nevirapine toxicity. ${ }^{16}$

The duration of antiretroviral therapy regimen used in CADR in HIV/AIDS patients which was 10-14 days in 5 patients $(29.4 \%)$ with morbilliform eruption and 10-14 days in 5 patients $(45.45 \%)$ with SJS. Furthermore, morbiliform rash related to nevirapine appear in 10 days to 6 weeks following initial therapy and are generally mild and self-sustaining. ${ }^{12,17}$

The other drugs suspected in morbiliform eruption cases were cefadroxil in 2 patients (13\%); paracetamol, clindamycin, anti-tuberculosis drugs, 1 patient each (7\%); cotrimoxazole 3 patients $(20 \%)$; and 4 patients $(26 \%)$ were unknown. In SJS cases, methampirone was prescribed to 1 patient $(16 \%)$, and 4 patients $(67 \%)$ were unknown. Cotrimoxazole, antituberculosis drugs such as isoniazide, rifampicin, ethambutol, pyrazinamide, streptomycin, and Fixed Drug Combination (FDC) anti-tuberculosis, antitoxoplasmosis combination treatment, pyrimethamine, sulfadiazine, leucorovine, clindamycin, and antifungal therapy such as fluconazole, itraconazole, and voriconazole were suspected to cause CADR in HIV/AIDS patients. ${ }^{12}$

The $\mathrm{CD}^{+}$count in morbilliform drug eruption cases were $1-100$ cell $/ \mathrm{mm}^{3}$ in 5 patients $(29.41 \%), 101-$ 200 cell $/ \mathrm{mm}^{3}$ in 2 patients $(11.76 \%), 201-349$ cells $/ \mathrm{mm}^{3}$ in 2 patients $(11.76 \%)$ and 8 patients did not have any data on $\mathrm{CD}^{+}$count on their medical records. The $\mathrm{CD}^{+}$count in Steven Johnson syndrome cases were $1-100$ cell $/ \mathrm{mm}^{3}$ in 3 patients $(27.27 \%), 101-200$ cell $/ \mathrm{mm}^{3}$ in 4 patients $(36.36 \%)$ and 4 patients $(36.36 \%)$ did not have any data on $\mathrm{CD}^{+}$count on their medical records. ADR due to antiretroviral drugs was presented to relate with CD4 count at the initial therapy. The Center for Disease Control and Prevention on HIV stated that complications can be more frequent and severe if the initial $\mathrm{CD}^{+}$cell count is low. ${ }^{18}$ Studies suggested most ADR patients had the $\mathrm{CD}^{+}$count below 200 cells $/ \mathrm{mm}^{3}$. ${ }^{6}$ However, the $\mathrm{CD}^{+}$ count higher than 250 cells $/ \mathrm{mm}^{3}$ is associated with morbilliform rash caused by nevirapine. ${ }^{19,20}$ In a 2011 study, it was mentioned that Nevirapine caused morbilliform rash in patients with the $\mathrm{CD}^{+}$count above 200 cells $/ \mathrm{mm}^{3} .{ }^{21}$ Additionally Kohlbrenner et. al, reported that the $\mathrm{CD}^{+}$cell count below 200 
cells $/ \mathrm{mm}^{3}$ and nevirapine increased the incidence of morbilliform rash. ${ }^{22}$

The therapies include systemic and topical medication. The treatment in morbilliform were 12 patients $(36.36 \%)$ received oral steroid, 7 patients $(21.21 \%)$ received antihistamines, 5 patients $(15.15 \%)$ received injection of steroids, 4 patients received wet dressing $\mathrm{NaCl} 0.9 \%, 4$ patients received (12.12\%) salycyl talc, 3 patients $(9.09 \%)$ received topical steroids and 2 patients $(6.06 \%)$ received topical antibiotics.

The treatment in SJS cases were 11 patients $(52.38 \%)$ received injection of steroids, 5 patients $(23.8 \%)$ received wet dressing $\mathrm{NaCl} 0.9 \%$ and 2 patients $(9.52 \%)$ received antihistamines, borax glycerin, salycyl talc and topical steroids. Oral corticosteroids have been reported to reduce CADR symptoms and short-term administration is considered safe in HIV/AIDS patients. Corticosteroid systemic were the most common therapies. The 2014 Clinical Practice Guidelines for Dermatology and Venereology of Dr. Soetomo General Academic Teaching Hospital specified that in the event of drug eruption, the suspected and cross-reactive drug should be avoided, oral antihistamines, topical corticosteroids, oral corticosteroids (prednisone 1-2 $\mathrm{mg} / \mathrm{kgBW} /$ day) only for severe cases. Antibiotics and injection of dexametasone $0.15-0.2 \mathrm{mg} / \mathrm{kgBW} /$ day $\mathrm{mg}$ is given to prevent infection and dexamethasone 5-20 mg daily iv. (0.15-0.2 $\mathrm{mg} / \mathrm{kgBW} /$ day) is given for erythroderma, decreased gradually rapidly as the skin lesions improved, chlorpheniramine maleate 3-4 mg/dose, 3 times a day potent topical steroids, for example: desoximetason ointment, $0.25 \%$ for dry skin. ${ }^{23,24}$

The obtained medical records of 2016-2017 showed that 6 patients $(21.4 \%)$ of 28 patients did not attend the follow-up visits. Follow-up visits are important to assess the patient's compliance with ARV drug consumption, assess the response of the therapy given, and evaluate the side effects of the substituting drugs.

Based on the findings in our study, patient with $\mathrm{HIV}$ in reproductive age group tend to experienced more CADR then other age group likely due to high prevalence of HIV patient in those age group. Morbilliform drug eruption was the most common CADR manifestation likely due to nevirapine (Duviral+Neviral) use as first line treatment for HIV patient in our center. Dermatological management varies widely based on individual assessment. Further research with longer period of observation needed provide better description on how frequent CADR occurred in HIV patient, the severity of CADR symptoms, and to reassure that use of some drugs, especially Nevirapine, lead to severe CADR symptoms so it can be a consideration to change therapy regimen for patient with HIV.

\section{REFERENCESS}

1. Altman K, Vanness E, Westergaard RP. Cutaneous manifestations of human immunodeficiency virus: a clinical update. Curr Infect Dis Rep 2015 Mar; 17 (3): 464-76.

2. Davarpanah M, Motazedian N, Jowkar F. Dermatological manifestations of HIV/AIDS individuals in Shiraz, South of Iran. J Global Infect Dis 2018; 10 (2): 80-3.

3. Malani PN. Human immunodeficiency virus. JAMA 2016 Jul 12; 316 (2): 238-39.

4. Maharani PN, Suwarsa O, Prodjosoewojo S. Clinical profile of adverse cutaenous drug reactions in patients with human immunodeficiency virus. AMJ 2020 Dec; 7 (4): 200-5

5. Warrington R, Silviu-Dan F, Wong T. Drug allergy. Allergy Asthma Clin Immunol 2018 Sep; 14 (S2): 129-39.

6. Sousa-Pinto B, Correia C, Gomes L, Gil-Mata S, Araújo L, Correia O, et al. HLA and delayed drug-induced hypersensitivity. Int Arch Allergy Immunol 2016; 170 (3): 163-79.

7. Pavlos R, White KD, Wanjalla C, Mallal SA, Phillips EJ. Severe delayed drug reactions. Immunology and Allergy Clinics of North America 2017 Nov; 37 (4): 785-815.

8. Zash R, Jacobson DL, Diseko M, Mayondi G, Mmalane M, Essex M, et al. Comparative safety of antiretroviral treatment regimens in pregnancy. JAMA Pediatr 2017 Oct 2; 171 (10): E1-9.

9. Karami Z, Mesdaghi M, Karimzadeh P, Mansouri M, Taghdiri MM, Kayhanidoost Z, et al. Evaluation of lymphocyte transformation test results in patients with delayed hypersensitivity reactions following the use of anticonvulsant drugs. Int Arch Allergy Immunol 2016; 170 (3): 158-62.

10. Khan K, Khan AH, Sulaiman SA, Soo CT, Akhtar A. Adverse drug reactions in HIV/AIDS patients at a tertiary care hospital in Penang, Malaysia. Jpn J Infect Dis 2016; 69 (1): 56-9.

11. Alexoudi I, Katsarou A, Paparizos V, Oikonomou K, Kourkounti S, Augerinou G, et al. Dermatological conditions associated with HIV medication in a cohort of Greek patients initiating antiretroviral therapy: 1988-2013. Journal of Virus Eradication 2018 Jan; 4 (1): 26-9.

12. Hidayati A, Budiono S, Triono E. Terapi anti retrovirus (ARV) pada pasien HIV dan AIDS. In: 
Manifestasi dan tatalaksana kelainan kulit dan kelamin pada pasien HIV/AIDS. Jakarta: Badan Penerbit Fakultas Kedokteran Universitas Indonesia; 2018. p. 293-313.

13. Deng Q, Fang X, Zeng Q, Lu J, Jing C, Huang J. Severe cutaneous adverse drug reactions of Chinese inpatients: a meta-analysis. An Bras Dermatol 2017 Jun; 92 (3): 345-9.

14. Brandariz D, Smithson A, Anton-Vazquez V. Drug reaction with eosinophilia and systemic symptoms related to antiretroviral treatment in human immunodeficiency virus patients. Indian J Sex Transm Dis 2017; 38 (2): 163-70.

15. Riono $\mathrm{P}$, Challacombe SJ. HIV in Indonesia and in neighbouring countries and its social impact. Oral Dis 2020 Sep; 26 (S1): 28-33.

16. Thakkar S, Patel T, Vahora R, Bhabhor P, Patel R. Cutaneous adverse drug reactions in a tertiary care teaching hospital in India: An intensive monitoring study. Indian J Dermatol 2017; 62 (6): 510-7.

17. Manchanda Y, Das S, Sarda A, Biswas P. Controversies in the management of cutaneous adverse drug reactions. Indian J Dermatol 2018 Apr; 63 (2): 125-30.

18. Birbal S, Dheda M, Ojewole E, Oosthuizen F. Adverse drug reactions associated with antiretroviral therapy in South Africa. Afr J AIDS Res 2016 Sep; 15 (3): 243-8.
19. Sachdeva RK, Sharma A, De D, Malhi J, Rewari $\mathrm{BB}$, Singh S, et al. Lamivudine-induced skin rash remains an underdiagnosed entity in HIV: a case series from a single center. JIAPAC 2016 Mar; 15 (2): 153-8.

20. Paik S. Fatal nevirapine-induced toxic epidermal necrolysis in a HIV infected patient. JCDR 2016; 10 (3): FD03-6.

21. Hoosen K, Mosam A, Dlova NC, Grayson W. An update on adverse cutaneous drug reactions in HIV/AIDS. Dermatopathology 2019 Jun 26; 6 (2): 111-25.

22. Kementerian Kesehatan Republik Indonesia. Pedoman nasional tatalaksana klinis infeksi HIV dan terapi antiretroviral pada orang dewasa dan remaja. Jakarta: Kementerian Kesehatan Republik Indonesia Direktorat Jenderal Pengendalian Penyakit dan Penyehatan Lingkungan; 2012.

23. Damayanti, Hutomo M, Prakoeswa C, Suyoso S. Sindroma Steven Johnson. In: Panduan praktik klinis SMF Ilmu Kesehatan Kulit dan Kelamin RSUD Dr Soetomo. Surabaya: Universitas Airlangga Press; 2014. p. 18-9.

24. Damayanti, Hutomo M, Prakoeswa C. Erupsi Obat Morbilis. In: Panduan praktik klinis SMF Ilmu Kesehatan Kulit dan Kelamin RSUD Dr Soetomo. Surabaya: Universitas Airlangga Press; 2013. p. 16-7. 